ISSN 0258-7122 (Print), 2408-8293 (Online)

Bangladesh J. Agril. Res. 43(1): 81-88, March 2018

\title{
RELATIVE ABUNDANCE OF INSECT PESTS AND THEIR PREDATORS ON BORO RICE
}

\author{
M. A. BAKAR ${ }^{1}$ AND M. M. H. KHAN ${ }^{2}$
}

\begin{abstract}
The study was conducted to know the relative abundance of insect pests and their predators on 5 boro rice varieties namely Arize tez, Teea, Sakti, Sathi and BRRI Dhan 28. In Arize Tez variety, short horned grasshopper revealed the highest percent relative abundance $(87.25 \%)$ at tillering stage and green rice leafhopper was only at panical initiation stage. Among insect predators, wasp showed the highest percent relative abundance $(33.33 \%)$ both at tillering and panical initiation stages. In Teea variety, the highest percent relative abundance of short horned grasshopper was recorded at tillering $(80.21 \%)$ and panicle initiation $(86.03 \%)$ stages while spider and lady bird beetle had $21.05 \%$ at tillering stage, wasp $(21.05 \%$ and $40.00 \%)$, damselfly $(21.05 \%$ and $40.00 \%)$ at tillering and panical initiation stages, respectively. In Sakti variety, short horned grasshopper had the highest percent relative abundance $(72.54 \%$ and $69.05 \%)$ at tillering and panicle initiation stages while dragonfly had $30.77 \%$ at tillering, wasp had $30.77 \%$ and $66.66 \%$ at tillering and panicle initiation stages. In Shathi variety, the highest percent relative abundance of short horned grasshopper was recorded at tillering $(59.46 \%)$ and panicle initiation $(52.27 \%)$ stages while wasp $(41.67 \%)$ at panical initiation stage. In variety BRRI dhan 28, the highest percent relative abundance of insect pests was recorded in short horned grasshopper $(76.73 \%$ and $86.05 \%)$ both at tillering and panicle initiation stages while in insect predators, wasp had $40 \%$ at tillering and $50 \%$ at panicle initiation stages but dragonfly had $50 \%$ only at panicle initiation stage.
\end{abstract}

Keywords: Insect pests, natural enemies, relative abundance, rice varieties.

\section{Introduction}

The production of boro rice is seriously hampered by the attack of insect pests. About 266 species of insect have been recorded as rice pests, of these 42 species are economically important in Bangladesh (Islam et al., 2003). Nine insect pests and 9 natural enemies in boro rice from seedling to reproductive stages have been recorded and the relative abundance of insect pests and natural enemies varied with different growth stages of rice plant. The highest percent relative abundance of green leafhopper $(41.79 \%)$ and wasp $(42.53 \%)$ are estimated at seedling stage, grasshopper (35.36\%) and dipteran fly (35.59\%) at early tillering stage while the highest percent relative abundance of rice bug (66.92\%) and ground beetle $(45.88 \%)$ are measured at maximum tillering stage having similar trend at reproductive stage (Bakar et al., 2014). Seven different insect pests namely yellow stem borer, rice bug, green leafhopper, short horned grasshopper, long

${ }^{1 \& 2}$ Department of Entomology, Patuakhali Science and Technology University, Dumki, Patuakhali, Bangladesh. 
horned grasshopper, leaf floder and brown planthopper while 7 insect predators viz., damselfly, ground beetle, long jawed spider, lynx spider, mirid bug, ichneumonid and lady bird beetle have been occurred in coastal rice habitat. The percent relative abundance of green leafhopper and spider are the highest at maximum tillering stage (Khan, 2013). The highest abundance of insect pests has varied with rice growth stages and observed as yellow rice stem borer at maximum tillering stage, green leafhopper at seedling stage, short horned grasshopper at early tillering stage, stink bug at maximum tillering and reproductive stages, rice bug at reproductive stage and rice hispa at early tillering stage. In case of natural enemies, the highest abundance of lady bird beetle, spider and dipteran fly has occurred at early tillering stage, ground beetle and damselfly at maximum tillering stage, and wasp at seedling stage (Bakar and Khan, 2015). Mukherjee et al. (2015) found the highest number of insect pests at panicle initiation stage (1808 insect pests/160 sweeps) and lowest at early tillering stage (131 insect pests/160 sweeps) while the highest number of natural enemies (1026/160 sweeps) has counted at seedling stage and the lowest at early tillering stage (386/160 sweeps). In Southern coastal region, only one published report is available on insect pests of boro rice. Therefore, the study was undertaken to study on the relative abundance of insect pests and their predators on different boro rice varieties.

\section{Materials and Methods}

The study was conducted in the research farm of Patuakhali Science and Technology University, Dumki, Patuakhali during boro season (November 2011 to May 2012) to know the relative abundance of insect pests and their predators on five boro rice varieties viz., Arize tez, Teea, Sakti, Sathi and BRRI Dhan 28. Seeds of different rice varieties were collected from Bangladesh Rice Research Institute. Seeds were sprouted by the farm labours by sowing on 28 November 2011 in well-prepared nursery beds. The study was conducted in randomized complete block design with 3 replications. Unit plot size was $5 \mathrm{~m} \times 4 \mathrm{~m}$. Fertilization was done according to BRRI recommended dose in experimental fields. Urea, TSP, MP, gypsum were applied at the rate of 270, 150, 120, 110 $\mathrm{kg} / \mathrm{ha}$ respectively. One third of the urea and full dose of other fertilizers were applied as basal dose at the time of final land preparation. The rest amount of urea was top dressed in two equal installments at maximum tillering and before panicle initiation stage. The seedlings were transplanted on 02 January 2012 into the prepared land using 2 seedlings per hill. Intercultural operations viz. gap filling, weeding etc. were done properly. Irrigation and drainage have done as per required at the experimental fields.

The insect pests of rice and their natural enemies were collected by a fine nylon cloth sweep net $(30 \mathrm{~cm}$ diameter). Data were collected on 15 February and 03 March, 2012 at tillering stage while at panicle initiation stage it was done on 30 March, 2012. Sweeping was done on the standing crop from the plant canopy 
level including the interspaces between plants as well as close to basal region of the plants as far as possible. In each field, 20 complete sweeps were made to collect the insect pests and their predators. Sampling was done at tillering and panicle initiation stages. Sampling was done in between 7:00-10:00 AM. The pests and predators insects from each field were collected separately in labeled container. The collected samples were properly preserved, identified, sorted and counted in the laboratory of the Department of Entomology, Patuakhali Science and Technology University. The samples were sorted and identified under stereoscopic microscope and magnifying glass, and percent relative abundance was calculated. Data were analyzed by using WASP (Web based Agricultural Statistical Package) for $t$ test and means were separated by critical difference (CD) value.

\section{Results and Discussion}

\section{Relative abundance of insect pests}

Relative abundance of insect pests in rice ecosystem is presented in Table 1. In Arize Tez variety, the highest percent relative abundance of short horned grasshopper $(87.25 \%)$ was recorded at tillering stage while the lowest was in long horned grasshopper $(3.75 \%)$. In case of panicle initiation stage, the highest percent relative abundance was in Short horned grasshopper (47.88\%) while the lowest in Green leaf hopper (1.96\%).

In Teea variety, the highest percent relative abundance of Short horned grasshopper was recorded at both tillering $(80.21 \%)$ and panicle initiation stages (86.03\%) while the lowest percent was in Stink bug (1.87\%) at tillering and Green leafhopper (1.07\%) at panicle initiation stage.

In Sakti variety, the highest percent relative abundance of Short horned grasshopper (72.54\%) and lowest in Green leaf hopper (2.33\%) was recorded at tillering stage. However, at panicle initiation stage, the similar trend was observed in Short horned grasshopper $(69.05 \%)$ while the lowest was in Stink bug $(1.00 \%)$.

In shathi variety, the highest percent relative abundance of Short horned grasshopper (59.46\%) was recorded at tillering stage and lowest was in Stink bug $(5.41 \%)$. But in case of panicle initiation stage, the highest was in Short horned grasshopper (52.27\%) and lowest was in Stink bug (6.82\%).

In BRRI dhan28, the highest percent relative abundance of Short horned grasshopper (76.73\%) was recorded at tillering stage and the lowest was in Rice bug $(2.33 \%)$. But in case of panicle initiation stage, the similar trend was in Short horned grasshopper (86.05\%) and lowest was in Long horned grasshopper $(1.16 \%)$. 
Table 1. Relative abundance of insect pests on different boro rice varieties at their tillering and panicle initiation stages during 2011-12 at Patuakhali

\begin{tabular}{|c|c|c|c|c|c|c|}
\hline \multirow[b]{2}{*}{ Rice variety } & \multirow[b]{2}{*}{ Insect Pests } & \multicolumn{2}{|c|}{ Mean abundance $(\%)$ at } & \multirow{2}{*}{$\begin{array}{c}\mathrm{T} \\
\text { ststistic }\end{array}$} & \multirow[b]{2}{*}{ df } & \multirow[b]{2}{*}{$\mathrm{P}$} \\
\hline & & $\begin{array}{l}\text { Tillering } \\
\text { stage }\end{array}$ & $\begin{array}{c}\text { Panicle } \\
\text { initiation stage }\end{array}$ & & & \\
\hline \multirow[t]{6}{*}{ Ariz tez } & Yellow rice stem borer & $5.45 \mathrm{ijk}$ & $0.00 \mathrm{j}$ & 30.12 & 7 & 0.01 \\
\hline & Short horned grasshopper & $87.25 \mathrm{a}$ & $49.40 \mathrm{c}$ & 47.88 & 7 & 0.01 \\
\hline & Long horned grasshopper & $3.75 \mathrm{jkl}$ & $5.88 \mathrm{gh}$ & -24.46 & 7 & 0.01 \\
\hline & Rice bug & $0.00 \mathrm{~m}$ & $37.30 \mathrm{e}$ & 0.42 & 7 & NS \\
\hline & Stink bug & $3.78 \mathrm{jkl}$ & $5.87 \mathrm{gh}$ & -29.82 & 7 & 0.01 \\
\hline & Green leafhopper & $0.00 \mathrm{~m}$ & $1.96 \mathrm{ij}$ & 0.51 & 7 & NS \\
\hline \multirow[t]{6}{*}{ Teea } & Yellow rice stem borer & $6.58 \mathrm{hi}$ & $0.00 \mathrm{j}$ & 47.55 & 7 & 0.01 \\
\hline & Short horned grasshopper & $80.21 b$ & $86.03 \mathrm{a}$ & -608.75 & 7 & 0.01 \\
\hline & Long horned grasshopper & $5.67 \mathrm{ij}$ & $5.36 \mathrm{gh}$ & 0.62 & 7 & NS \\
\hline & Rice bug & $0.00 \mathrm{~m}$ & $6.46 \mathrm{gh}$ & 0.43 & 7 & NS \\
\hline & Stink bug & $1.87 \mathrm{~lm}$ & $1.07 \mathrm{j}$ & 76.12 & 7 & 0.01 \\
\hline & Green leafhopper & $5.66 \mathrm{ij}$ & $1.07 \mathrm{j}$ & 252.30 & 7 & 0.01 \\
\hline \multirow[t]{6}{*}{ Sakti } & Yellow rice stem borer & 4.64ijk & $0.00 \mathrm{j}$ & 443.05 & 7 & 0.01 \\
\hline & Short horned grasshopper & $72.54 d$ & $69.05 b$ & 5.498 & 7 & 0.01 \\
\hline & Long horned grasshopper & $16.28 \mathrm{f}$ & $11.90 \mathrm{f}$ & 6.68 & 7 & 0.01 \\
\hline & Rice bug & $0.00 \mathrm{~m}$ & $11.90 \mathrm{f}$ & 0.52 & 7 & NS \\
\hline & Stink bug & $4.65 \mathrm{ijk}$ & $1.00 \mathrm{j}$ & 5.17 & 7 & 0.01 \\
\hline & Green leafhopper & 2.331 & 4.78hi & -2.92 & 7 & 0.05 \\
\hline \multirow[t]{6}{*}{ Shathi } & Yellow rice stem borer & $8.11 \mathrm{~h}$ & $0.00 \mathrm{j}$ & 15.03 & 7 & 0.01 \\
\hline & Short horned grasshopper & $59.46 \mathrm{e}$ & $52.27 \mathrm{c}$ & 10.90 & 7 & 0.01 \\
\hline & Long horned grasshopper & $0.00 \mathrm{~m}$ & $0.00 \mathrm{j}$ & 0.46 & 7 & NS \\
\hline & Rice bug & $13.51 \mathrm{~g}$ & $40.91 \mathrm{~d}$ & -29.66 & 7 & 0.01 \\
\hline & Stink bug & 5.41ijk & $6.82 \mathrm{gh}$ & -2.15 & 7 & NS \\
\hline & Green leafhopper & $13.51 \mathrm{~g}$ & $0.00 \mathrm{j}$ & 25.21 & 7 & 0.01 \\
\hline \multirow[t]{6}{*}{ BRRI dhan 28} & Yellow rice stem borer & 4.65ijk & $0.00 \mathrm{j}$ & 8.68 & 7 & 0.01 \\
\hline & Short horned grasshopper & $76.73 \mathrm{c}$ & $86.05 \mathrm{a}$ & -6.38 & 7 & 0.01 \\
\hline & Long horned grasshopper & $12.78 \mathrm{~g}$ & $1.16 \mathrm{j}$ & 13.85 & 7 & 0.01 \\
\hline & Rice bug & 2.331 & $8.14 \mathrm{~g}$ & -6.82 & 7 & 0.01 \\
\hline & Stink bug & $0.00 \mathrm{~m}$ & 4.65hi & 0.32 & 7 & NS \\
\hline & Green leafhopper & $3.49 \mathrm{kl}$ & $0.00 \mathrm{j}$ & 6.51 & 7 & 0.01 \\
\hline $\mathrm{CV}(\%)$ & & 5.68 & 8.87 & & & \\
\hline $\mathrm{CD}(0.01)$ & & 2.068 & 3.234 & & & \\
\hline
\end{tabular}

Means within a column followed by same letter(s) are not significantly different by critical difference $(\mathrm{P} \leq 0.01)$ 
Table 2. Relative abundance of insect predators on different boro rice varieties at their tillering and panicle initiation stages during 2011-12 at Patuakhali

\begin{tabular}{|c|c|c|c|c|c|c|}
\hline \multirow{2}{*}{$\begin{array}{c}\text { Rice } \\
\text { variety }\end{array}$} & \multirow[b]{2}{*}{ Insect predators } & \multicolumn{2}{|c|}{ Mean abundance $(\%)$ at } & \multirow[b]{2}{*}{$\mathrm{T}$ ststistic } & \multirow[b]{2}{*}{ df } & \multirow[b]{2}{*}{$\mathrm{P}$} \\
\hline & & $\begin{array}{l}\text { Tillering } \\
\text { stage }\end{array}$ & $\begin{array}{c}\text { Panicle } \\
\text { initiation stage }\end{array}$ & & & \\
\hline \multirow[t]{6}{*}{ Ariz tez } & Spider & $16.67 \mathrm{~g}$ & $0.00 \mathrm{k}$ & 19.93 & 7 & 0.01 \\
\hline & Dragon fly & $11.11 \mathrm{~h}$ & $22.22 \mathrm{f}$ & -12.11 & 7 & 0.01 \\
\hline & Damsel fly & $11.12 \mathrm{~h}$ & $11.11 \mathrm{i}$ & -0.01 & 7 & NS \\
\hline & Lady bird beetle & $16.67 \mathrm{~g}$ & $11.11 \mathrm{i}$ & 4.90 & 7 & 0.01 \\
\hline & Wasp & $33.33 b$ & $33.33 d$ & 0.00 & 7 & NS \\
\hline & Dipteran fly & $11.11 \mathrm{~h}$ & $22.22 \mathrm{f}$ & -12.11 & 7 & 0.01 \\
\hline \multirow[t]{6}{*}{ Teea } & Spider & $21.05 f$ & $0.00 \mathrm{k}$ & 24.83 & 7 & 0.01 \\
\hline & Dragon fly & $0.00 \mathrm{j}$ & $13.33 \mathrm{~h}$ & 0.41 & 7 & NS \\
\hline & Damsel fly & $21.05 f$ & $40.00 \mathrm{c}$ & -12.94 & 7 & 0.01 \\
\hline & Lady bird beetle & $21.05 \mathrm{f}$ & $6.67 \mathrm{j}$ & 9.80 & 7 & 0.01 \\
\hline & Wasp & $21.05 \mathrm{f}$ & $40.00 \mathrm{c}$ & -12.94 & 7 & 0.01 \\
\hline & Dipteran fly & $15.80 \mathrm{~g}$ & $0.00 \mathrm{k}$ & 17.60 & 7 & 0.01 \\
\hline \multirow[t]{6}{*}{ Sakti } & Spider & $23.08 \mathrm{ef}$ & $0.00 \mathrm{k}$ & 18.30 & 7 & 0.01 \\
\hline & Dragon fly & $30.77 \mathrm{c}$ & $16.67 \mathrm{~g}$ & 7.97 & 7 & 0.01 \\
\hline & Damsel fly & $7.68 \mathrm{i}$ & $0.00 \mathrm{k}$ & 9.12 & 7 & 0.01 \\
\hline & Lady bird beetle & $0.00 \mathrm{j}$ & $16.67 \mathrm{~g}$ & 0.51 & 7 & NS \\
\hline & Wasp & $30.77 \mathrm{c}$ & $66.66 \mathrm{a}$ & -19.52 & 7 & 0.01 \\
\hline & Dipteran fly & $7.69 \mathrm{i}$ & $0.00 \mathrm{k}$ & 9.09 & 7 & 0.05 \\
\hline \multirow[t]{6}{*}{ Shathi } & Spider & $0.00 \mathrm{j}$ & $0.00 \mathrm{k}$ & 0.00 & 7 & NS \\
\hline & Dragon fly & $25.00 \mathrm{de}$ & $16.67 \mathrm{~g}$ & 4.23 & 7 & 0.01 \\
\hline & Damsel fly & $25.00 \mathrm{de}$ & $8.33 \mathrm{j}$ & 11.73 & 7 & 0.01 \\
\hline & Lady bird beetle & $12.50 \mathrm{~h}$ & $8.33 \mathrm{j}$ & 3.29 & 7 & 0.05 \\
\hline & Wasp & $12.50 \mathrm{~h}$ & $41.67 \mathrm{c}$ & -16.13 & 7 & 0.01 \\
\hline & Dipteran fly & $25.00 \mathrm{de}$ & $25.00 \mathrm{e}$ & 0.00 & 7 & NS \\
\hline \multirow{6}{*}{$\begin{array}{l}\text { BRRI } \\
\text { dhan } 28\end{array}$} & Spider & $26.67 d$ & $0.00 \mathrm{k}$ & 31.81 & 7 & 0.01 \\
\hline & Dragon fly & $13.33 \mathrm{~h}$ & $50.00 \mathrm{~b}$ & -40.15 & 7 & 0.01 \\
\hline & Damsel fly & $6.67 i$ & $0.00 \mathrm{k}$ & 7.90 & 7 & 0.01 \\
\hline & Lady bird beetle & $0.00 \mathrm{j}$ & $0.00 \mathrm{k}$ & 0.00 & 7 & NS \\
\hline & Wasp & $40.00 \mathrm{a}$ & $50.00 \mathrm{~b}$ & -6.83 & 7 & 0.01 \\
\hline & Dipteran fly & $13.33 \mathrm{~h}$ & $0.00 \mathrm{k}$ & 11.28 & 7 & 0.01 \\
\hline $\mathrm{CV}(\%)$ & & 6.67 & 5.07 & & & \\
\hline $\mathrm{CD}(0.01)$ & & 2.418 & 1.837 & & & \\
\hline
\end{tabular}

Means within a column followed by same letter(s) are not significantly different by critical difference $(\mathrm{P} \leq 0.05$ and $\mathrm{P} \leq 0.01)$. 


\section{Relative abundance of insect predators}

Relative abundance of insect predators in rice ecosystem is presented in Table 2. In Ariz tez variety, the highest percent relative abundance of wasp (33.33\%) was recorded at tillering stage while the lowest in dipteran fly $(11.11 \%)$. But in case of panicle initiation stage, the highest was of wasp (33.33\%) and the lowest was in lady bird beetle $(11.11 \%)$ which was statistically identical to damselfly (11.11).

In teea variety, the highest percent relative abundance of spider $(21.05 \%)$ was recorded at tillering stage which was statistically identical to damselfly, lady bird beetle and wasp while the lowest percent was in dipteran fly $(15.80 \%)$ was recorded. At panicle initiation stage, wasp $(40.00 \%)$ had the highest and lady bird beetle possessed the lowest percent $(6.67 \%)$ relative abundance (Table 2 ).

In sakti variety, the highest percent relative abundance was found in dragonfly (30.77\%) which was statistically identical to wasp $(30.77 \%)$ at tillering stage while the lowest was in damselfly $(7.68 \%)$ followed by dipteran fly $(7.69 \%)$. At panicle initiation stage, the highest percent relative abundance was in wasp $(66.66 \%)$ while the lowest was in lady bird beetle $(16.67 \%)$ which was statistically identical to dragonfly (16.67\%).

In shathi variety, the relative abundance of insect predators was the highest in dragon fly $(25.00 \%)$ which was statistically identical to damselfly $(25.00 \%)$ and dipteran fly $(25.00 \%)$ while the lowest was in lady bird beetle $(12.50 \%)$ at tillering stage. But in case of panicle initiation stage, the highest was in wasp $(41.67 \%)$ and the lowest was in lady bird beetle $(8.33 \%)$.

In BRRI dhan 28 , significantly the highest percent relative abundance was recorded in wasp $(40.00 \%)$ while the lowest was in damsel fly $(6.67 \%)$ at llering stage. But in case of panicle initiation stage the highest percent relative abundance was in dragon fly $(50.00 \%)$ which was statistically identical to wasp $(50.00 \%)$.

The findings of the present study are in agreement with the findings of Rahman et al. (2004) who reported that the abundance of insect pests and natural enemies was influenced by different growth stages of rice plant. The highest abundance was observed at reproductive stage and the lowest was at mid tillering stage. Khan and Alam (2007) also found that the highest number of insect pests and natural enemies was found at reproductive stage and the lowest was at mid tillering stage. Bakar and Khan (2016) reported that diversity indices of insect pests and their natural enemies were found to be affected by the combined effect of rice growth stages and management practices in boro rice. Mukherjee and Khan (2014) found that the highest percent relative abundance $(44.14 \%)$ was in the population of rice bug and in ground beetle of 
insect predators while lowest percent $(0.31 \%)$ was in rice stem borer and in dragonfly $(0.51 \%)$ of insect predators. Lanjar et al. (2002) found that four species infesting rice crop which were Hieroglyphus banian (rice grasshopper), Oxya nitidula (small green grasshopper), Chrotogonus trachypterus (surface grasshopper), and Aiolopus tamulus [A. thalassinus] (small grasshopper). C. trachypterus was recorded in maximum number (12.8 nymphs and 39.2 adults/observation) during July-October under a mean temperature of $37.95^{\circ} \mathrm{C}$. Tsueda et al. (2002) studied on the occurrence of rice bugs (a total of 22 species) in rice fields. They also observed that Stenotus rubrovittatus was the important species and the peak occurrence of it coincided with the date of heading of early-ripening rice. Afsana and Islam (2001) studied abundance of lady bird beetles and found five species of lady bird beetles viz. M. discolor, M. crocea, Coccinella transversahs, $C$. septempunctata and Brumoides suturalis in irrigated rice fields at Gazipur in Bangladesh. Among them M. discolor was the most dominant species comprising about $92.9 \%$ of the total ladybird beetle populations.

\section{References}

Afsana, N. and Z. Islam. 2001. Abundance of ladybird beetles in irrigated rice environment in Bangladesh, diurnal activity pattern of Micraspis discolor (Fab.) and its influence on rice grain sterility. Bangladesh J. Entomol. 11 (1-2): 55-66.

Bakar, M. A., M. M. H. Khan, M. H. Rahman and M. J. Uddin. 2014. Occurrence and relative abundance of insect pests and natural enemies at different growth stages of BRRI dhan29. J. Patuakhali Sci. and Tech. Univ. 5(1): 45-54.

Bakar, M. A. and M. M. H. Khan. 2015. Rice growth stages and management practices affecting the abundance of insect pests and natural enemies in BRRI dhan29. Bangladesh J. entomol. 25(2): 55-66.

Bakar, M. A. and M. M. H. Khan. 2016. Diversity of insect pests and natural enemies as influenced by growth stages and pest management practices in rice. Bangladesh $J$. Agril. Res. 41(3): 461-470.

Islam, Z., N. Ahmed, M. Haq, N. Afsana and M. M. Haque. 2003. Some ecological aspects of rice bug (Leptocorisa spp.) in Bangladesh. Bangladesh J. Entomol. 13(1): 85-96.

Khan, M .M. H. and M. M. Alam. 2007. Influence of management practices and growth stages of rice on the abundance and diversity of insect pests and natural enemies. Ann. Bangladesh Agric. 11(2): 21-32.

Khan. M. M. H. 2013. Abundance and diversity of insect pests and natural enemies in coastal rice habitat. Bangladesh J. Entomol. 23(1): 89-104.

Mukherjee, P. and M. M. H. Khan. 2014. Influence of rice growth stages and neighbouring plants on relative abundance and diversity indices of arthropod insect pests and natural enemies in rice ecosystem. Bangladesh J. Entomol. 24(1): 75-89. 
Mukherjee, P., M. M. H. Khan, M. J. Uddin and M. H. Rahman. 2015. Effects of habitats, growth stages and weather factors on arthropod insect pests and natural enemies. $J$. Agrofor. Environ. 9(1\&2): 135-138.

Rahman, M.A., M.M.H. Khan, M.F. Hasan and M.M. Alam. 2004. Incidence and abundance of insect pests and their natural enemies at different growth stages of rice. J. agric. educ. technol. 7(1 and 2): 19-24.

Tsueda, H., M. Yajima, Y. Taguchi and T. Suzuki. 2002. Occurrence tendency of rice sting bugs in South flat area of Gifu Prefecture. Proc. of the Kansai Plant Protection Soc. 4: 13-20. 